\title{
Impacts of mining activities on soil properties: case studies from Morocco mine sites
}

\author{
Leila Benidire ${ }^{1}$, Loubna Benidire ${ }^{2}$, Ali Boularbah ${ }^{1-3 *}$ \\ ${ }^{1}$ Cadi-Ayyad University, Laboratoire de Bioresources et Securité Sanitaire des Aliments, Faculté des Sciences et Techniques -Marrakech, BP 549, \\ M-40000, Guéliz, Marrakech, Morocco \\ 2 Ibn Zohr University, Plant Biotechnology Laboratory "BiotecV”, Faculty of Sciences, Agadir. Laayoune Higher School of Technology, Laayoune, \\ Morocco \\ ${ }^{3}$ Mohammed VI Polytechnic University (UM6P), AgrobioSciences Program, Benguerir, Morocco \\ * A. Boularbah, a.boularbah@uca.ac.ma, a.boularbah@uca.ma, tel: +33 212 524433163; Fax: +33 212 524433170, ORCID iD: https://orcid.org/0000- \\ 0001-6036-3936
}

Received: 15.08 .2020

Accepted: 02.02.2021

Associated editor: Ł. Uzarowicz

\section{Keywords}

Moroccan mines

Abandoned mines

Environmental impacts

Soil pollution

Land rehabilitation

\begin{abstract}
Due to its very rich and varied geological heritage, the Moroccan subsoil contains many mining deposits that are subject to large-scale exploitation and extraction (mainly phosphates, base metals and precious metals) assigning to this sector an important role in the country's economic development. However, the exploitation of these mineral resources can present serious negative influence on the environment. Indeed, mining activities can disrupt natural environments in several ways, e.g. by altering landscapes, depositing large amounts of hazardous tailings and discharging polluted liquid and atmospheric effluents. Thus, it causes significant environmental damage with negative impacts on air, water and soil quality as well as the loss of biodiversity. Growing concerns about the consequences of mining activities, particularly mining waste, have led many researchers to assess the extent of the environmental damage they have caused. This review summarizes the most important research finding published on the environmental impact assessment of mining industries. Particular attention is paid to some metal ore mines, mainly abandoned ones, occurring across Morocco. The results of the environmental assessments have shown that the abandoned tailings dumps have caused severe contamination of the environment and its compartments. However, the major impact was observed in soils around the mining zones. Thus, particularly in sulphide-rich mines, such as Kettara, Draâ Lasfar, Ouixane, Axara and Sétolazar mines, the tailings with high acid-generating potential have led to a significant $\mathrm{pH}$ level decrease (down to pH 2) and to a severe metal contamination of soils. In many affected areas, toxic metal concentrations exceed standard levels admitted for agricultural soils (1.5 mg of Cd $\mathrm{kg}^{-1}$, $300 \mathrm{mg}$ of $\mathrm{Cu} \mathrm{kg}^{-1}, 150 \mathrm{mg}$ of $\mathrm{Pb} \mathrm{kg}^{-1}$ and $300 \mathrm{mg}$ of $\mathrm{Zn} \mathrm{kg}^{-1}$ ). Currently, this pollution continues to spread through these sites to the environment due to the lack of proper remediation of these mining lands. The persistence of this situation, therefore, poses a risk not only to the environment but also to the health and safety of the local population living near these sites.
\end{abstract}

\section{Introduction}

In Morocco, as in many countries around the world, mining industry contributes significantly to the national economic development. The importance of this sector is reflected in its contribution to gross domestic product (GDP), its important share in national exports and its beneficial effects on regional and rural development through the creation of new jobs. Both globally and in Africa, the country was able to occupy a prominent place for a number of mineral substances. Morocco is thus the world's leading exporter of phosphate, ranked as the world's second-largest producer of barite and one of the main producers of silver in Africa (De Boer et al., 2018; Oshokoya and Tetteh, 2018). This is explained by the existence of a favorable and diversified geological context which has made it possible to develop mining activity in many regions of the national territory.

If the socio-economic benefits of mining have been favorable to the country's development, the same does not apply for its impact on the environment. Indeed, it is well known that mining and metallurgical processes in all their phases, i.e. extraction, processing, transport, and smelting, alters the natural landscape and cause serious environmental impacts (Ainoo et al., 2009; Matschullat and Gutzmer, 2012). In addition, the large 
volumes of contaminated wastes generated by the extraction process, which are generally stored on the surface, can release dangerous pollutants that can persist in the environment for long periods (Nieva et al., 2018). Thus, mining waste can pose a serious threat to the surrounding soils and to the biota (Boularbah et al., 2006a, 2006b; El Adnani et al., 2006, 2007; El Khalil et al., 2008; Benidire et al., 2020). The pollutants contained in these wastes can also affect the quality of surface water and groundwater, leading to local contamination of rivers and sediments through erosion and leaching of mining wastes and can lead to a further water pollution by the transport of solid particles such as suspended solids (Bouabdli et al., 2004; El Khalil et al., 2008; Makhoukh et al., 2011; Bouzekri et al., 2019). Even years after mining ceases, most of its adverse effects continue to persist over large areas of land. The growing awareness of the possible adverse effects that mining industries can cause has led the Moroccan government to react with a number of regulations to protect the environment from these activities. However, the absence of regulations ensuring the rehabilitation of land after the mining closure in the 1951 mining code, which governed the sector until its reform in 2015, have led several owners to abandon them without any reclamation. These abandoned mines, estimated at over 200 mines nationwide (Khalil et al., 2013), have had varying degrees of impact on the surrounding environment depending on the nature of wastes left behind (e.g. acid generating tailings). Thus, since the late 1990s, many studies in Morocco have focused on evaluating the extent of the environmental damage associated with this mining waste as well as possible options to mitigate their negative effects. Therefore, the objective of this review is to (1) provide an overview of the impact of mining operations on soils and the environment, (2) provide a collection of case studies on the most studied Moroccan mines, and (3) give a brief overview of the techniques tested for the remediation of metalcontaminated soils in Moroccan mining case.

\section{Overview of mining industry in Morocco}

Moroccan mining industry is considered as one of the main support activities of the national economy, contributing to $10 \%$ of the country's gross domestic product (GDP) and representing around $20.9 \%$ of national exports (website 1). The phosphate rock industry, which contributes to the employment of approximately 40000 persons (website 2) is the major source of export revenue for the government. Indeed, in terms of production value, phosphate rock is the most important ore in Morocco and accounted for about $93 \%$ of the value of the country's mining production (website 2). Morocco is holding approximately $75 \%$ of the global phosphate rock reserves, and is the world's thirdlargest producer of phosphates after China and the United States (De Boer et al., 2018; Taib, 2019). In addition to phosphate rock, the country is also known for its world output share of Arsenic (16\%), Barite (10\%), Cobalt (2\%), Silver (1.5\%) and Fluorite (1\%) (Oshokoya and Tetteh, 2018).

The position that the mining sector occupies is explained, first of all, by the existence of an extremely varied geological context, which includes land belonging to different geological eras. Moroccan deposits are distributed in four main structural areas. From the south of the country to the north, there is the Anti-Atlas domain, the Meseta domain, the Atlas domain and the Rifain domain. The Anti-Atlas domain contains occurrences of manganese, precious metals ( $\mathrm{Au}$ and $\mathrm{Ag}$ ) and strategic metals (Co, Sn, Ti and W). The Meseta domain contains polymetallic mineralization (W, $\mathrm{Cu}, \mathrm{Mo}, \mathrm{Au}, \mathrm{Pb}, \mathrm{Zn}, \mathrm{Ag}$ ). The barite, $\mathrm{Cu}, \mathrm{Fe}, \mathrm{Pb}$, $\mathrm{Mn}$ and $\mathrm{Zn}$ ores occur in the Atlas domain. The Sb ores, smectitic clays, strategic metals (Co, Sn, Ti and W) and Zn ores (website 3) occur in the Rifain domain.

\section{Soils and environmental damages associated to mining activities}

Mining is one of the main sources of heavy metal environmental pollution worldwide. Indeed, intensive extraction of valuable minerals releases large quantities of volatile elements and toxic dust particles into the environment, contributing to serious pollution of aquatic and terrestrial ecosystems (Jordán and D'Alessandro, 2004).

It should be noted that, mining activity itself affects very often only relatively small areas (Nriagu and Pacyna, 1988; Salomons, 1995). However, the main problems associated with the extractive industry are related to mine waste dumps, which can cause large-scale local environmental impacts. Due to their chemical nature, mainly related to a very low content of organic materials, a low nutrient content and a very high concentration of metals, mining deposits create a hostile environment which inhibits plant growth (Wong et al., 1998; Boularbah et al., 2006a, 2006b; El Khalil et al., 2008; Probst et al., 2009). Without a vegetation cover, these materials become very vulnerable to water and wind erosion and thus become a continuous source of pollution of the surrounding environment. Mining can cause significant environmental damage, with negative impacts on landscapes (Fig. 1), air, water and soil quality.

Soil degradation is one of the most noticeable manifestations of mining and related activities. Indeed, the soils around mining sites are very often heavily affected by multi-metal contaminants ( $\mathrm{Cd}, \mathrm{Cu}, \mathrm{Zn}$ and $\mathrm{Pb}$ ) thus making the use of the land strictly limited (Simón et al., 1999; Boularbah et al., 2006a; El Khalil et al., 2008; El Hamiani et al., 2010; El Hamiani et al., 2015). Mining can affect soils over large areas, causing deleterious effects on soil properties and components, such as degradation of soil structure and horizons, disruption of soil microbial communities' structure and nutrient cycles (Benidire et al., 2016; Benidire et al., 2019), which consequently leads to the destruction the natural vegetation (Ghose and Kundu, 2004; Sheoran et al., 2010). Therefore, the lack of surface-protecting vegetation cover leaves contaminated materials exposed to wind and water erosion (Boularbah et al., 2006a, 2006b; Sheoran et al., 2010). Throughout the mining activity and even after cessation of operations, the tailings ponds left on site continue to be a major source of contamination and disturbance of the surrounding ecosystem. 


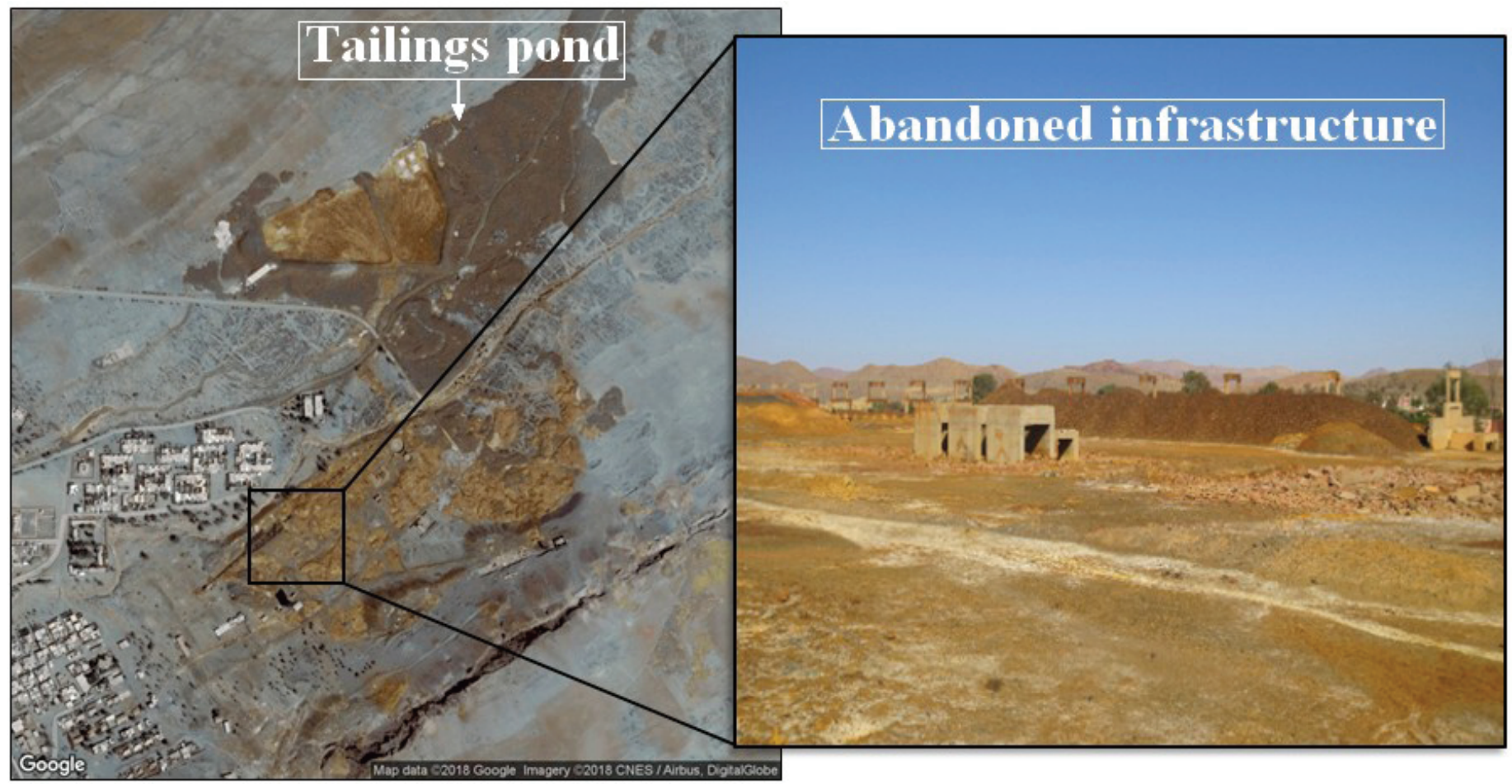

Fig. 1. Mining impact on Landscape, Kettara mine case, Marrakech, Morocco

\section{Results of research on Moroccan mines impacts}

Even though investigations on the health risks associated with mining activities have already been carried out since the late 1940s in Morocco (Mechali and Rodier, 1946; Rodier, 1947), studies on their impacts on surrounding soils and environment did not begin until the late 1990s and early 2000s. Since then, several groups of researchers become increasingly interested in studying the effects of mining waste on the environment, particularly in abandoned mine sites. The various investigations performed in recent years by Moroccan researchers' teams covered a wide range of questions about mining sites, including mineralogy and chemical nature of tailings left-in-place; fate and transport of these contaminated substrates in surface water, groundwater, soil and air; as well as their effect on living organisms. However, when exploring published articles, we found that the majority of studies have focused on evaluating the effects of tailings on physico-chemical properties of the compartments surrounding mining area (i.e soil, water, sediments, etc.) and assessment of the degree and extent of metal pollution in the environment, while little information has been reported about their effects on biota. Among the numerous studies carried out on this subject, 10 of the most studied Moroccan mining sites were selected for this review. Thus, a brief description of each mine and their main impacts reported in the published articles are summarized in Table 1 and 2.

\subsection{Beni Bou Ifrour-Ouixane district case study}

The Beni Bou Ifrour-Ouixane is a ferruginous district located southwest of the Nador city (Fig. 2). It includes a collec- tion of former iron mines, of which Ouixane, Axara both openpit mines, and Sétolazar an underground mine were the most productive ones. Starting from 1914 to 1976, the district was exploited for iron oxide and iron sulfide minerals (Bouabdellah et al., 2012). During its operation, all the mines in the district produced more than $65 \mathrm{Mt}$ of iron, with a volume of $1.5 \mathrm{Mm}^{3} / \mathrm{yr}$ of waste rock (Lakrim et al., 2011). The results of investigations conducted by Lakrim et al. (2011, 2012, 2016) on this district, showed that tailings heaps have an overall mineralogy made up of high percentages of oxides, hydroxides and iron sulfides. Moreover, mining waste, groundwater and drainage of surface water collected from operating zones exhibited a very low $\mathrm{pH}(\leq$ $\mathrm{pH}$ 3) and anomalous metal concentrations, in particular of Fe and in $\mathrm{S}$ with a maximum value recorded in Sétolazar mining effluents $(7.78 \% \mathrm{~S}$ and $2.88 \% \mathrm{Fe})$. Based on the physico-chemical data, Lakrim et al. (2012, 2016) also generated a mapping of vulnerable areas to metal pollution and acid mine drainage (AMD) for the mining district, through the Geographic Information System (GIS). Results of these studies showed that regions closest to the exploitation zone are the most vulnerable and represent the highest risks to the surrounding environment.

\subsection{The Upper-Moulouya lead district case study (Aouli, Mibladen and Zed'da)}

The Upper-Moulouya district is a lead-mining district located in the northeastern region of Morocco in the upper Moulouya river valley. It is by far one of the most important lead producing area in the country (Raddi et al., 2011; Bouabdellah and Sangster, 2016). The most famous and studied mines in this district are: the underground mines of Aouili and Mibladen 


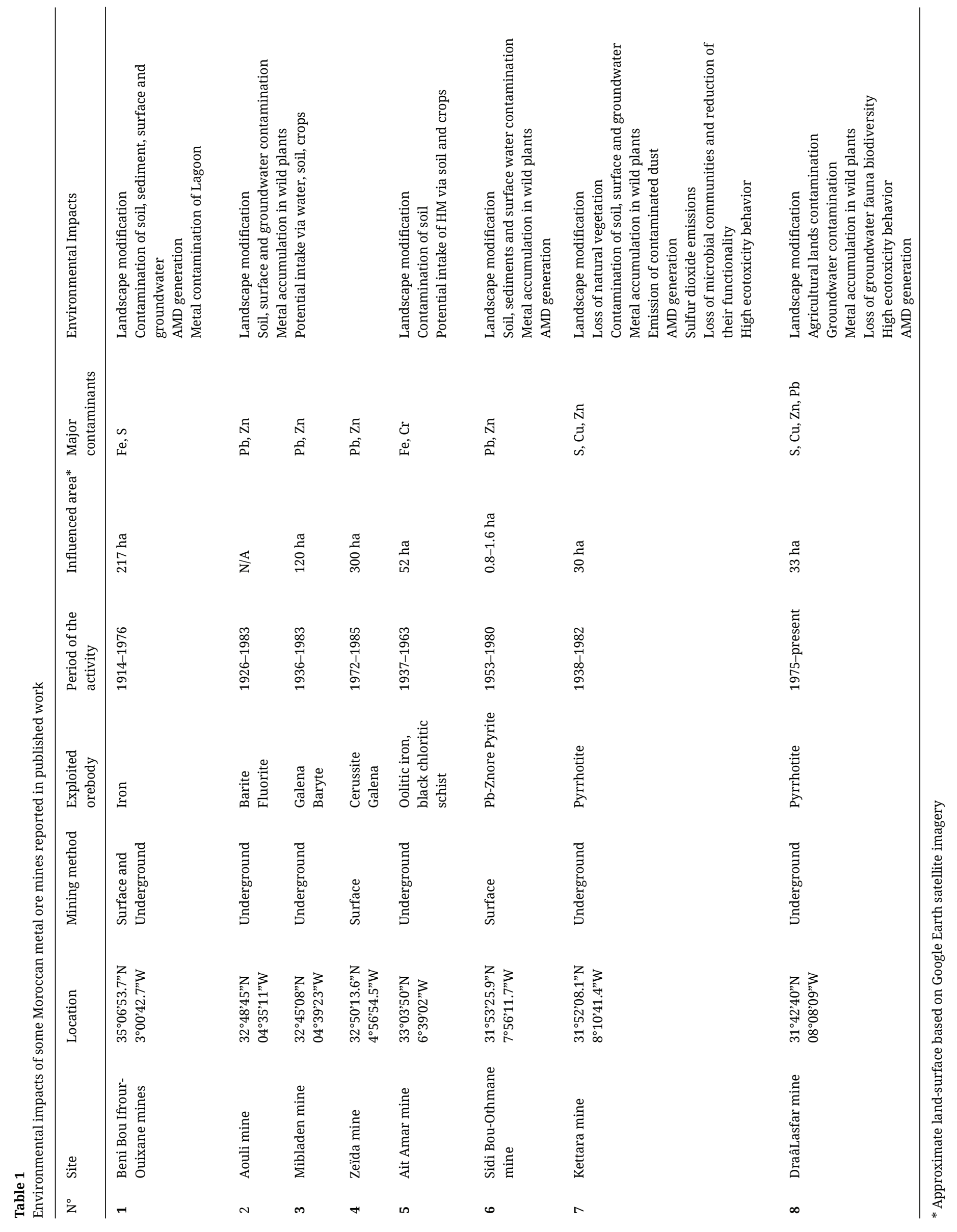




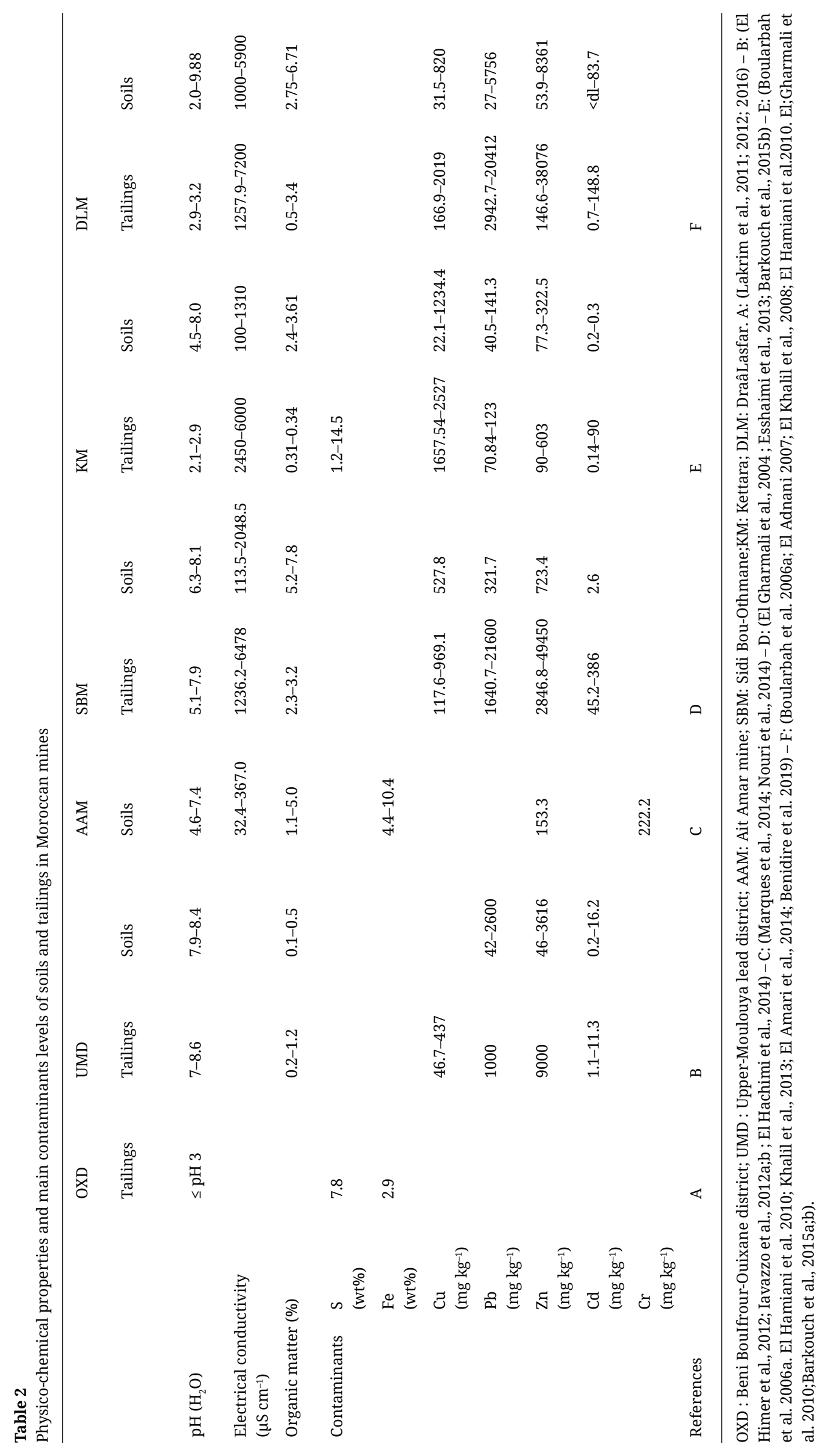




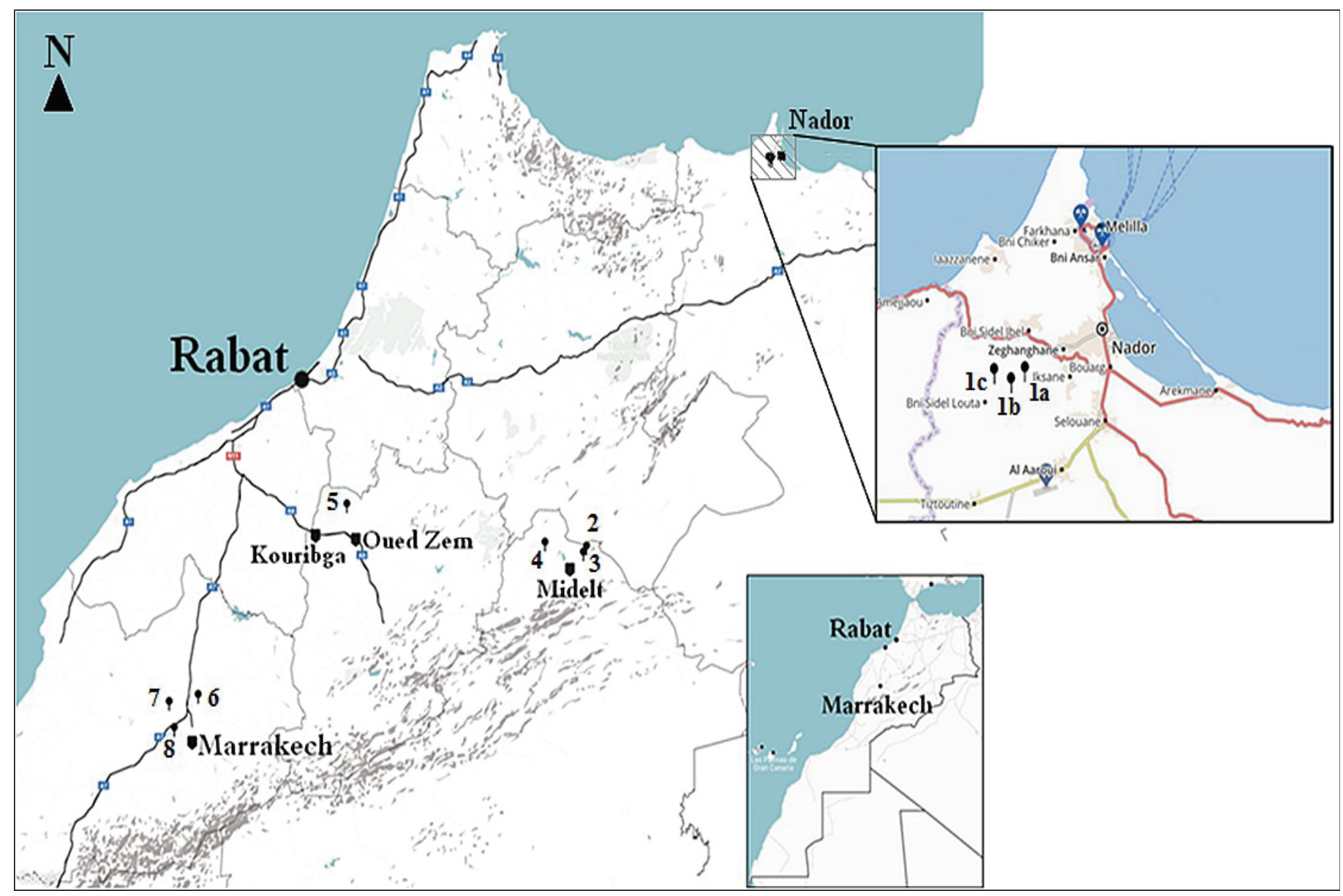

Beni Bou Ifrour-Ouixane mines: 1a - Setolazar mine; 1b - Axara mine and 1c - Ouiksane mine; 2 - Aouli mine; 3 - Mibladen mine; 4 - Zed'da mine; 5 - Ait Amar mine; 6 - Sidi Bou-Othmane mine; 7 - Kettara mine; 8 - Draâ Lasfar mine.

Fig. 2. Location of some metal ore mines in Morocco

and the open-pit mine of Zed'da. From 1926, mining operations started in the Aouli deposit (located $25 \mathrm{~km}$ northeast of Midelt) followed by the exploitation of the Mibladen mine in 1936 (15 $\mathrm{km}$ northeast of Midelt), which lasted until their closure in 1983. The Zed'da deposit is located $30 \mathrm{~km}$ northwest of Midelt, the mine began operations in 1972, and its resources had been mined out by 1985 (Raddi et al., 2011). The majority of studies conducted in this mining district have been concerned with their impact on soil and water quality of the Moulouya river. However, few studies investigated the effect of metal-contaminated tailings on plants growing around mines. Compared to Aouli and Mibalden mines, Zed'da has been the subject of several investigations. The natural landscape of the Upper-Moulouya valley has been seriously modified by the mining activities. In the three mining sites, deep excavations filled with water, mine adits, stripping wastes as well as abandoned pits are covering the exploitation areas, where also a lack of vegetation cover is observed (Iavazzo et al., 2012a). In Zed'da, three tailings piles, covering an area of about 80 ha, were deposited in the open air near the river bed. In Mibladen, mining dumps were deposited on the banks and bed of the Mibladen river (a tributary of the Moulouya river) over an area of approximately 120 ha (El Hachimi et al., 2013). Tailings of all mining areas were found to have an alkaline $\mathrm{pH}$ (7-8.6), low conductivity and very low organic matter contents (0.1-0.5). In addition, mining wastes were found to be highly contaminated by heavy metals, particularly by $\mathrm{Pb}$ and $\mathrm{Zn}$ (maximum values detected are $1000 \mathrm{mg}$ of $\mathrm{Pb} \mathrm{kg}{ }^{-1}$ and $9000 \mathrm{mg}$ of $\mathrm{Zn} \mathrm{kg}^{-1}$ ) (El Himer et al., 2012; Iavazzo et al., 2012a, 2012b; El Hachimi et al., 2014). Lack of vegetation, fine particle-size $(<2 \mathrm{~mm})$ with relatively homogeneous distributions makes residues of the three mines particularly subject to wide dispersion in the environment, and as such a potential source of metal contamination for the surrounding compartments (Iavazzo et al., 2012a, 2012b; El Hachimi et al., 2013). In fact, several authors have reported high concentrations of metals in soils collected near the piles, as well as a large spatial distribution of these contaminants in the surrounding area (Baghdad et al., 2006; Iavazzo et al., 2012a, 2012b; El Himer et al., 2012; El Hachimi et al., 2014). In addition, Hadi (2015) demonstrated the implication of wind erosion as a factor contributing to the dissemination of contaminants from tailings to the surrounding soils and environment. Indeed, by using geostatistical methods, a spatial distribution of pollutants in the soils around Zed'da was carried. Results of this study revealed that the areas located in the prevailing wind directions of the mine tailings were enriched in heavy metals. Regarding the 
evaluation of the effect of mining activity on water and sediments' quality, studies have shown that surface and groundwater collected near mining zones were significantly affected by the former mining activities. Thus, high levels of $\mathrm{Pb}$ and $\mathrm{As}$, very often exceeding the limit defined by the WHO (2008) for drinking water $\left(10 \mu \mathrm{g} \mathrm{L}^{-1}\right)$, were detected in these sites (Iavazzo et al., 2012a; Bouzekri et al., 2020). Though metals level in surface waters of the Moulouya River, downstream of the mining activities, were complied with the Moroccan drinking-water quality standards, their concentration in sediments has largely exceeded the international standards for river sediments (88 $\mathrm{mg}$ of $\mathrm{Zn} \mathrm{kg}^{-1}$ and $22 \mathrm{mg}$ of $\mathrm{Pb} \mathrm{kg}{ }^{-1}$ ) (Bouabdli et al., 2004; Makhoukh et al., 2011; Bouzekri et al., 2019). Finally, although the Zed'da mining area has low metal mobility due to its alkaline $\mathrm{pH}$, some plants growing in this area have been found to be able to accumulate large amounts of metals in their tissues. In fact, in four studied species namely Reseda phyteuma L., Matthiola longipetala L., Stipa tenacissima L. and Artemisia herbaalba L., high concentrations of metals were recorded particularly in their roots. Lead was the most accumulated metal in these plants, with values observed by researchers for varying between 29 and $1332.7 \mathrm{mg}$ of $\mathrm{Pb} \mathrm{kg}^{-1}$ (Baghdad et al., 2006; El Himer et al., 2012; El Azhari et al., 2017).

\subsection{Ait Amar mine case study}

The Ait Amar oolithic iron deposit is located at $25 \mathrm{~km}$ northwest of Oued Zem city (Fig. 2). It is an open-pit mine that was converted to underground mining. Extraction of iron ore at this site started from 1937 and mining operation lasted for 26 years, until its closure in 1963 (Boushaba and Michard, 2011). The mining area is characterized by low vegetation cover, mainly consisting of Echinops spinosus L., Eryngium ilicifolium, Eryngium triquetrum (Nouri et al., 2013; Nouri and Haddioui, 2017a, 2017b). All studies carried out on this site only concerned the soil compartment and the effect of pollution on some organisms. Some of these surveys also emphasized the potential environmental risks of this metal-contaminated soil by using various ecological indexes. According to physicochemical analysis, soils of Ait Amar mining area are characterized by relatively acidic $\mathrm{pH}$, relatively low conductivity and high organic carbon content (1.06-5.01\%) (Marques et al., 2014; Nouri et al., 2014). Generally, concentrations of Fe, $\mathrm{Zn}$ and $\mathrm{Cr}$ in soil were above some European soil screening value. According to the results, soils exhibited very high levels of Fe (about 43.55 $\left.10^{4} \mathrm{mg} \mathrm{kg}^{-1}\right)$ and $\mathrm{P}\left(0.9210^{4} \mathrm{mg} \mathrm{kg}^{-1}\right)$ with slightly high $\mathrm{Cr}$ and $\mathrm{Zn}$ contents (222.16 mg kg-1 and $153.3 \mathrm{mg} \mathrm{kg}^{-1}$, respectively) (Nouri et al., 2014). Results of some indexes, such as pollution index, geoaccumulation index and enrichment factor, showed that the Ait Amar soils were moderately polluted with $\mathrm{Cr}$, Fe and P. However, potential ecological risk estimated a low risk for all metal except for $\mathrm{Pb}$ (Nouri, 2016). Toxicity tests carried out by Madani et al. (2015) on enchytraeids (Enchytraeus bigeminus) and predatory mites (Hypoaspis aculeifer) reveled an overall lack toxicity of soils collected from the mining area, with a significant toxic impact on E. bigeminus observed only in plots containing high concentrations of $\mathrm{Cd}$ or $\mathrm{Cu}$. Similarly, the $\mathrm{Ar}$ - throbacter globiformis test conducted by Marques et al. (2014) revealed that most of Ait Amar mining soils were not toxic to the bacteria. A similar outcome was found by Nouri and Haddioui (2017a) using the Microtox ${ }^{\circledR}$ test, the authors also testified that iron mine tailings did not significantly affect the metabolic and structural diversity of microbial populations. In addition, according to the result of phytotoxicity assay, no negative effect of these soils was observed over Lepidium sativum L (Nouri and Haddioui, 2017b). However, studies on the metals uptake by spontaneous native plants growing in mining zone revealed their high potential to accumulate significant concentration of metals in shoots. Indeed, metal concentrations were relatively high in some species and even exceeded the critical concentrations defined by Kabata-Pendias and Pendias (2001), such as Echinops spinosus L which recorded the highest $\mathrm{Cd}, \mathrm{Cu}, \mathrm{Zn}$ concentrations (0.989, 29.190 and $175.347 \mathrm{mg} \mathrm{kg}^{-1}$, respectively) (Nouri et al., 2013).

\subsection{Mines of the Jebilet massif (Marrakech)}

Jebilet is a massif, located north of Marrakech, mainly composed of rocky plains and low hills. The massif is made up of three main areas: the western, central and eastern Jebilet. The ore deposits in the Jebilet district are the massive sulphide base metals type, mainly composed of $\mathrm{Cu}, \mathrm{Pb}, \mathrm{Zn}$, and Fe minerals (Yahyaoui and Essaifi, 2011). The central Jebilet host several identified ore deposits, which were mined during the mid-twentieth century. The environmental impacts of these mining sites have been the subject of many studies. Among these sites, only three will be presented in this section namely: Sidi Bou-Othmane, Kettara and Draâ Lasfar (Fig. 2).

The Sidi Bou-Othmane mine is located upstream of agricultural area within $30 \mathrm{~km}$ north of Marrakech. It is a former open-pit zinc-lead mine which operated between 1953 and 1980 (Esshaimi et al., 2013). The mining area is characterized by a heterogeneous vegetation structure with scarce patches of spontaneous plants (Midhat et al., 2019). After the mine closure, huge amounts of mine tailings were left on site in the open air. The tailings contain gang minerals such as chlorite, quartz, talc and muscovite (El Gharmali et al., 2004). The tailings were characterized by a slightly acidic to neutral $\mathrm{pH}$ with high electrical conductivity values (EC) (average value of 6478 $\mu \mathrm{S} \mathrm{cm}{ }^{-1}$ ) indicating a high salinity level. Measurements of metals in these materials showed very high levels of $\mathrm{Pb}, \mathrm{Zn}, \mathrm{Cu}$ and $\mathrm{Cd}$, with values ranging from 1640.7 to $21600 \mathrm{mg}$ of $\mathrm{Pb} \mathrm{kg}^{-1}$, 2846.8 to $49450 \mathrm{mg}$ of $\mathrm{Zn} \mathrm{kg}^{-1}, 117.6$ to $969.1 \mathrm{mg}$ of $\mathrm{Cu} \mathrm{kg}^{-1}$ and 45.2 to $386 \mathrm{mg}$ of $\mathrm{Cd} \mathrm{Kg}^{-1}$ (El Gharmali et al., 2004; Esshaimi et al., 2013; Barkouch et al., 2015b). The results of Esshaimi et al. (2013) and Barkouch et al. (2015b, 2016), related to the assessment of metal contamination in the surrounding environment, showed that soils collected in the vicinity of the mine and soils of agricultural lands located near the mine exploitation (approximately $600 \mathrm{~m}$ ) were highly affected by the mining activity. In fact, in most of these soils the total metal levels have exceeded the standard levels admitted for agricultural soil established by European Directive 86/278/EEC, which equals 1.5 $\mathrm{mg}$ of $\mathrm{Cd} \mathrm{kg}^{-1}, 300 \mathrm{mg}$ of $\mathrm{Cu} \mathrm{kg}^{-1}, 150 \mathrm{mg}$ of $\mathrm{Pb} \mathrm{kg}^{-1}$ and $300 \mathrm{mg}$ 
of $\mathrm{Zn} \mathrm{kg}^{-1}$ (Council of the European Communities 1986). Results of the chemical speciation data of metals in soils and tailings showed that $\mathrm{Zn}$ and $\mathrm{Pb}$ were the most likely to pose environmental and health risks as they are the most potentially bioavailable elements in soil (Esshaimi et al., 2013; Barkouch et al., 2015b). El Gharmali et al. (2004) demonstrated that surface waters downstream of the mining area were highly contaminated by metals. Thus, the concentrations of dissolved $\mathrm{Pb}, \mathrm{Zn}, \mathrm{Cu}$ and Cd reported by this author exceeded $100 \mu \mathrm{g} \mathrm{L}^{-1}$ in the collected water. The investigation carried out by Midhat et al. (2019) on the accumulation of metal by spontaneous plants growing in the mining area showed that metals concentrations in most of the collected spaces exceed normal levels defined by KabataPendias and Pendias (2001).

Kettara is a former underground mine, located approximately $35 \mathrm{~km}$ northwest of Marrakech. The mine operated for 44 years (1938-1982) and mainly mined pyrrhotite which, since 1964, was used to produce sulfuric acid (Boularbah et al., 2006a; Hakkou et al., 2008a; Babi e al., 2016). The mine produced approximately 3 million tons of sulfur-rich mining waste (1.2$14.5 \mathrm{wt} \%$ sulfur), dumped over an area of approximately 16 ha (Hakkou et al., 2008a). Measurements of metals in these tailings revealed very high levels exceeding the background contents defined by Kabata-Pendias and Pendias (2001) for non-contaminated soils (1-15 mg As kg-1, 6-60 mg Cu kg-1, 10-70 mg Pb kg-1, 1-15 mg Zn kg-1) (Boularbah et al., 2006a; Hakkou et al., 2008a, 2008b; Khalil et al., 2013; El Amari et al., 2014). The metals concentrations were also far beyond the geochemical background values established for the Kettara soils $\left(\approx 13.9 \mathrm{mg} \mathrm{As} \mathrm{kg}^{-1}, \approx 43.8\right.$ $\mathrm{mg} \mathrm{Cu} \mathrm{kg}{ }^{-1}, \approx 21.8 \mathrm{mg} \mathrm{Pb} \mathrm{kg}{ }^{-1}, \approx 102.6 \mathrm{mg} \mathrm{Zn} \mathrm{kg}{ }^{-1}$ ) (Khalil et al., 2013). According to Hakkou et al. (2008a), these tailings are highly acid-generating, characterized by high acid-producing potential (51-453 $\mathrm{kg} \mathrm{CaCO}_{3} \mathrm{t}^{-1}$ ) and a very low acid-neutralizing potential (0-9 $\left.\mathrm{kg} \mathrm{CaCO}_{3} \mathrm{t}^{-1}\right)$. The environmental concerns in Kettara region are mainly associated with these AMD-generating wastes. Indeed, environmental surveys carried out at this mine revealed that the surrounding area was strongly affected by the tailings pond. Therefore, high metal concentrations, which exceed the Canadian soil quality guideline for residential use, were recorded in soils collected around and especially downstream of the mine tailings. Thus, El Khalil et al. (2008) reported that concentrations of $\mathrm{Zn}$ and $\mathrm{Cu}$ in soils affected by stream water, which flow through mine tailings, to be $398-2175 \mathrm{mg} \mathrm{kg}^{-1}$ and 22.1-578 $\mathrm{mg} \mathrm{kg}^{-1}$, respectively. In addition, a strong inhibition of the biotest MetPLATE ${ }^{\mathrm{TM}}$ was recorded by the authors in these soils; indicating their high ecotoxicity. This toxicity was also confirmed by the assessment of microbial communities of Kettara polluted soils. Indeed, a study conducted on rhizospheric soils collected from contaminated zones showed that, metal contamination had significantly reduced the abundance of all soil microbial groups and the activity of soil dehydrogenase. However, as confirmed by the DGGE analysis, no adverse effect of metal contamination was observed on soil bacterial diversity (Benidire et al., 2020). Geochemical maps elaborated by Khalil et al. (2013) on the basis of metal concentrations and using GIS showed that, mining wastes are mainly responsible for contamination of metals in soils in the area and that the most populated area of the Kettara village was affected by the highest pollution. As the tailings were deposited over the natural path of a wadi, and even if it flows only during the rainy season, the quality of its water downstream was found to be seriously polluted with toxic metals. The maximum values reported by Toughzaoui et al. (2015) were $1 \mathrm{mg} \mathrm{Cr} \mathrm{L}^{-1}, 240 \mathrm{mg} \mathrm{Cu}$ $\mathrm{L}^{-1}$, $4 \mathrm{mg} \mathrm{Ni} \mathrm{L}{ }^{-1}$, $147 \mathrm{mg} \mathrm{Zn} \mathrm{L}^{-1}$. The wadi and the small stream flowing through the tailings were identified as one of the main sources of soil pollution in the area (El Khalil et al., 2008; Khalil et al., 2013; El Amari et al., 2014). Despite the wide distribution of metal contaminants in the environment, no contamination by these elements occurred in the wells of the Katara village. However, high levels of major ions and high EC, exceeding the Moroccan and WHO quality standard for drinking water, were recorded in wells downstream of the tailings pond (El khalil et al., 2008; Lghoul et al., 2014; Toughzaoui et al., 2015; Moyé et al., 2017). In order to identify potential hyperaccumulators and to assess the risk associated with plants growing in the Ketarra region, metal uptake in some plants was investigated by several researchers. Thus, according to metal concentration thresholds proposed by Kabata-Pendias and Pendias (2001), excessive concentrations of $\mathrm{Cu}$ and $\mathrm{Zn}\left(>20 \mathrm{mg} \mathrm{kg}^{-1},>100 \mathrm{mg} \mathrm{kg}^{-1}\right.$, respectively), were detected in shoots of several spontaneous species growing near the mine and some plants growing in domestic gardens (Boularbah et al., 2006b; El Hamiani et al., 2010; Midhat et al., 2017). The high translocation factor (TF) in some of these spontaneous plants ( $\mathrm{TF}>1$ ) may explain these results ( $\mathrm{El}$ Hamiani et al., 2010; Midhat et al., 2017). With the exception of Lamarckia aurea which was classified by Midhat et al. (2017) as a potential accumulator of $\mathrm{Cu}$ and $\mathrm{Zn}$ (Bioaccumulation Factor $>1$ ). All species identified in the Kettara mining area were classified as a non-hyperacumulator plant (Boularbah et al., 2006b; Midhat et al., 2017; Benidire et al., 2020). A study carried out by El Hamiani et al. (2015) to assess whether edible and aromatic plants grown in home gardens pose any health risk to consumers reveled that, the consumption of these plants is relatively free of risks as the health risk index values were lower than 1 .

The Draâ Lasfar mine, located about $16 \mathrm{~km}$ northwest of Marrakech, is a polymetallic mine mainly containing pyrrhotite associated with sulphides. It is an underground mine operating since 1975 to produce base metals such as $\mathrm{Zn}, \mathrm{Pb}$ and $\mathrm{Cu}$ (Ibouh et al., 2011). The Draâ Lasfar mine is considered the last active mine in the Jebilet-Guemassa volcanic-hosted massive sulphide province (Bouabdellah et al., 2016). Throughout the mining activity, tons of tailings have piled up at the operating zone over 0.8-1.6 ha (El Fadeli et al., 2015) and they are still continuing to pile up in the present. In the surrounding area, several productive agricultural lands can be seen on the edge of the mine, while the Tansift River is located only a few hundred meters away from the site. This mine is one of the few active mines to have undergone an environmental impact study. Several studies have reported the adverse effects of this mine on soil, surface water and groundwater of the surrounding environment, as well as on biota. The studies conducted by Boularbah et al. (2006a) and El Khalil et al. (2008) revealed that the acid tailings ( $\mathrm{pH}$ 3.2) of this mine, which contain a high concentration of toxic metals (148.8 mg Cd kg-1, 2019 mg Cu kg-1, $20412 \mathrm{mg} \mathrm{Pb}$ 
$\mathrm{kg}^{-1}$ and $38076 \mathrm{mg} \mathrm{Zn} \mathrm{kg}{ }^{-1}$ ), had a significant impact on soils surrounding the site. Indeed, high metals concentrations have been detected in soils of the surrounding area and the soils collected from agricultural land near the exploitation which was affected by the AMD. Thus, for the majority of studied soils, the metal levels exceeded the standard values admitted for agricultural soil established by European Directive 86/278/EEC. Moreover, based on the results of the biotest MetPAD ${ }^{\mathrm{TM}}$, Boularbah et al. (2006a) reported a very high ecotoxicity of all agricultural soils affected by AMD. This toxicity is meanly attributed to the high mobility of metal in soil. Indeed, the study conducted by Barkouch et al. (2015a) on the chemical speciation of metals in agricultural soils neighboring mining zone, showed that $\mathrm{Cd}$ and $\mathrm{Cu}$ were the most potentially mobile elements. Based on the contamination factors and the pollution index calculated for the soils surrounding the Draa Lasfar mine and the GIS contour mapping of metal pollutants, it was confirmed that the pollution was mainly attributed to mining activity and that areas neighboring the site were the most affected by it (Avila et al., 2012; Barkouch and Pineau, 2016). Besides wind erosion, it has been shown by El Khalil et al. (2008) that surface runoff is also one of the main factors contributing to soils pollution in this area. In fact, high metal concentrations were detected in mine tailings runoff $\left(0.86-1.67 \mathrm{mg} \mathrm{Cd} \mathrm{kg}^{-1}\right.$; 23.0-189.7 mg Cu $\mathrm{kg}^{-1}$ and $279.2-2009 \mathrm{mg} \mathrm{Zn} \mathrm{kg}^{-1}$ ), which were associated with acute toxicity confirmed by the biotest MetPLATE ${ }^{\mathrm{TM}}$. All soil affected by these stream waters exhibited as well high concentrations of water-soluble metals (up to $272.5 \mathrm{mg} \mathrm{Cu} \mathrm{kg}^{-1}$ and 365.2 $\mathrm{mg} \mathrm{Zu} \mathrm{kg}{ }^{-1}$ ) and high ecotoxicity levels. The uptake of metals by plants growing in these contaminated soils was examined in order to identify potential hyperaccumulators and to assess the risk associated with the presence of metals in plant shoots. Thus, the result obtained by Boularbah et al. (2006b) showed that, according to limits defined by Kabata-Pendias and Pendias (2001), several plant species accumulated in their shoots excessive amounts of $\mathrm{Cu}, \mathrm{Pb}$; while toxic levels of $\mathrm{Zn}$ were accumulated by four species, namely Echium plantagineum L., Nitrosalsola vermiculata L. and Cynodon dactylon L. Nevertheless, based on the metal transfer factor, none of these species was identified as hyperaccumulator plants. Given that the mine is located very close to the river and that several wells intended for agricultural use are located all around the site; several studies have therefore been carried out to assess the impact of mining activity on surface and groundwater. According to the results of these studies, the metal levels in all the wells examined did not exceed the limit defined by WHO (2008) for drinking water. However, unlike upstream wells, the EC values and the major ion levels in groundwater collected downstream of the mine exceed greatly the Moroccan standards for water intended for irrigation use (El Adnani et al., 2006, 2007; El Khalil et al., 2008; Bahir et al., 2018; Boujghad et al., 2019). Moreover, the fauna distribution analysis carried out by El Adnani et al. (2006, 2007) showed that, compared to the wells upstream, several pollution-sensitive species have completely disappeared from the groundwater collected downstream the mining site, such as Giustia gofasi, Heideella cf. andreae, Tethysbaena atlantomaroccana, Marocolana sp2, Typhlocirolana haouzensis, Met- acrangonyx paurosexualis and Metacrangonyx spinicaudatus. Unlike groundwater in which the metal content was not very high, surface water sampled from the river downstream of the mine showed rather excessive levels of toxic metals, especially dissolved form $\mathrm{Cd}\left(1420 \mathrm{mg} \mathrm{kg}^{-1}\right), \mathrm{Cu}\left(3090 \mathrm{mg} \mathrm{kg}^{-1}\right)$ and $\mathrm{Pb}$ (180 $\mathrm{mg} \mathrm{kg}^{-1}$ ). This outcome is attributed to the contaminated acid effluents resulting from mining activity which drain directly into this part of the river (El Gharmali et al., 2004).

\section{General state of soil remediation in Moroccan mining areas}

Before the 2015 reforms, there were no regulations governing land reclamation after mines' closure in Moroccan mining legislation. Thus, more than 200 mines have been abandoned across the country for several years without any action to restore or mitigate the damage caused by these past activities (Khalil et al., 2013). To our knowledge and to date, no restoration measure on any of the Moroccan abandoned metal ore mines were applied either by the former owners of these sites or by the government. Nevertheless, an exception was made by the OCP group (Office Chérifien des Phosphates) which, from 2013, began to take responsibility for the environmental damage generated by its closed phosphate mines. Thus, through its new program called “Green Mine”, the group has achieved the rehabilitation of a cumulative phosphate mining surface of approximately 3870 ha located mainly in Khouribga city. The program also aims to restore the group's old metal ore mines such as the abandoned Kettara mine.

In the last few years, many research groups have been interested in studying reclamation options of past mine tailings areas. In fact, several studies have been carried out to assess the effectiveness of physico-chemical techniques in reducing the impacts of acid-generating wastes, such as the use of by-products (e.g. lime, phosphate wastes, sugar industrial sludge, marble, cement kiln dust and fly ash) as an amendment to neutralize AMD and immobilize metal pollutants (Hakkou et al., 2009; Zerhouni et al., 2016; Nfissi et al., 2017; Midhat et al., 2018; El Rasafi and Haddioui, 2020) or the application of store-and-release cover system using phosphate limestone wastes to reduce water infiltration into the tailings (Bossé et al., 2013, 2015). Regarding bioremediation techniques, several studies have focused on identifying potential native plant species to be used for the phytostabilization or phytoextraction process (Boularbah et al., 2006b; El Kheir et al., 2008; Nouri et al., 2013; Midhat et al., 2017, 2019; Benidire et al., 2020). Other studies have focused on the selection of rhizosphere bacteria with high potential to be used for assisted phytoremediation of polluted sites (El Aafi et al., 2015; Benidire et al., 2016; Sbabou et al., 2016; Lamin et al., 2019). Some researchers have also tested the feasibility and efficiency of phytoremediation of mine tailings assisted by amendments and / or plant growth-promoting microorganisms (El Faiz et al., 2015; Ouaryi et al., 2016; Midhat et al., 2018). Despite the progress that research has led in this field, all of the studied options remain in the testing stage and so the issues caused by mining waste in Morocco continue to persist to this day. 


\section{Conclusions}

This review gives a global overview on pollution levels and environmental damage caused by metalliferous mines across Morocco. Based on data collected from articles published in this topic, it appears that in most cases reported in this review the areas surrounding the mines, and more particularly soils and surface waters, were seriously polluted by heavy metals released from contaminated tailings dumps. In addition, in the absence of a monitoring and management program of these sites, hazardous mining wastes continue to contribute to further degradation of the environment and, therefore, poses risks to the health and safety of population groups living nearby.

The environmental impact of the mining industry in Morocco is getting worse over the years, especially with the increasing demand for minerals linked to the continued economic growth of the country. The most effective approach to mitigate the pollution of natural resources caused by these activities is the effective control of potential sources of contaminants, especially mining wastes. Emphasis should also be placed on the application of efficient, sustainable and economically affordable remediation technologies for the rehabilitation of mine sites such as phytoremediation. The environmental legislation and regulation of the country must take into account that mining closure plan should be one of the main parts of any mining project in order to avoid contamination of aquatic and terrestrial ecosystems with metals.

\section{Acknowledgements}

This study was financially supported by the Centre National de Recherche Scientifique et Techniques [grant no. PPR 22/2015]. The authors would like to thank Dr. A. Pandey for proofreading and correcting the English of this article.

\section{References}

Aboudrar, W., Schwartz, C., Morel, J. L., Boularbah, A., 2013. Effect of nickel-resistant rhizosphere bacteria on the uptake of nickel by the hyperaccumulator Noccaea caerulescens under controlled conditions. Journal of Soils and Sediments 13(3), 501-507. https://doi.org/10.1007/ s11368-012-0614-x

Ainoo, A.O., Amegbey, N., Suglo, R.S., 2009. Environmental impact of mining and ore processing - A case study at satellite goldfields limited. [In:] Luginaah I.N., Yanful E.K. (Eds.) Environment and Health in SubSaharan Africa: Managing an Emerging Crisis. Springer, Dordrecht, 53-64. https://doi.org/10.1007/978-1-4020-9382-1_4

Avila, M., Perez, G., Esshaimi, M., Mandi, L., Ouazzani, N., Brianso, J. L., Valiente, M., 2012. Heavy metal contamination and mobility at the mine area of Draa Lasfar (Morocco). The Open Environmental Pollution and Toxicology Journal 3(1), 2-12. doi: 10.2174/187639790120 3010002

Babi, K., Asselin, H., Benzaazoua, M., 2016. Stakeholders’ perceptions of sustainable mining in Morocco: A case study of the abandoned Kettara mine. The Extractive Industries and Society 3(1), 185-192. https:// doi.org/10.1016/j.exis.2015.11.007

Baghdad, B., Naimi, M., Bouabdli, A., Sonnet, P., Lutts, S., 2006. Heavy metals in tailings, soils and vegetation of an abandoned lead mine land in Morocco. Ecologia Mediterranea 32(1), 85-91.
Bahir, M., Tahar, M. A., Goumih, A., Ouhamdouch, S., Rouissa, A., 2018. Impact of mine polymetallic Draa Sfar South on the aquifer of central Haouz (Morocco). Journal of Materials and Environmental Sciences 9(5), 1405-1410. https://doi.org/10.26872/jmes.2018.9.5.153

Barkouch, Y., Edine, K. M., Pineau, A., 2015a. Study of potential environmental risk of trace metallic elements in mine tailings: Case of Draa Lasfar functional mine in Marrakech-Morocco. African Journal of Agricultural Research 10(33), 3246-3252. https://doi.org/10.5897/ AJAR2015.10029

Barkouch, Y., El Fadeli, S., Pineau, A., 2016. Contamination by trace elements of agricultural soils around Sidi Bou Othmane in abandoned mine tailings in Marrakech, Morocco. Pollution 2 (1), 93-101. https:// dx.doi.org/10.7508/pj.2016.01.010

Barkouch, Y., Pineau, A., 2016. Impact of mine tailings on surrounding soils: Case study of Draa Lasfar mine, Marrakech-Morocco. Environmental Resources Research 4(1), 57-64. https://doi.org/10.22069/ ijerr.2016.3153

Barkouch, Y., Yannick, F., Pineau, A., 2015b. Study of potential environmental risk of metallic trace elements in mine tailings: case study of Sidi BouOthmane abandoned mine in Marakech, Morocco. Journal of Materials and Environmental Science 6(10), 2722-2728. https://doi. org/10.5897/AJAR2015.10029

Benidire, L., Pereira, S. I. A., Castro, P. M., Boularbah, A., 2016. Assessment of plant growth promoting bacterial populations in the rhizosphere of metallophytes from the Kettara mine, Marrakech. Environmental Science and Pollution Research 23(21), 21751-21765. https://doi. org/10.1007/s11356-016-7378-6

Benidire, L., Pereira, S. I., Naylo, A., Castro, P. M., Boularbah, A., 2020. Do metal contamination and plant species affect microbial abundance and bacterial diversity in the rhizosphere of metallophytes growing in mining areas in a semiarid climate? Journal of Soils and Sediments 20(2), 1003-1017. https://doi.org/10.1007/s11368-019-02475-4

Bossé, B., Bussiere, B., Hakkou, R., Maqsoud, A., Benzaazoua, M., 2013. Assessment of phosphate limestone wastes as a component of a storeand-release cover in a semiarid climate. Mine Water and the Environment 32(2), 152-167. https://doi.org/10.1007/s10230-013-0225-9

Bossé, B., Bussičre, B., Hakkou, R., Maqsoud, A., Benzaazoua, M., 2015. Field experimental cells to assess hydrogeological behaviour of storeand-release covers made with phosphate mine waste. Canadian Geotechnical Journal 52(9), 1255-1269. https://doi.org/10.1139/cgj-20140263

Bouabdellah M., Sangster D.F., 2016. Geology, Geochemistry, and Current Genetic Models for Major Mississippi Valley-Type $\mathrm{Pb}-\mathrm{Zn}$ Deposits of Morocco. [In:] Bouabdellah M., Slack J. (Eds), Mineral Deposits of North Africa. Mineral Resource Reviews. Springer, Cham.

Bouabdellah, M., Hibti, M., Maacha, L., Zouhair, M., Velasco, F., 2016. Geologic, Hydrothermal, and geochemical relationships between bimodal magmatism and massive sulphide mineralization in the Central Jebilet-Guemassa province (Western Moroccan Hercynides). [In:] Bouabdellah, M., Slack, F.J., (Eds.), Mineral Deposits of North Africa. Springer, Cham, 437-459.

Bouabdellah, M., Lebret, N., Marcoux, E., Sadequi, M., 2012. The Beni Bou Ifrour-Ouixane mines (Eastern Rif), NeogeneSkarn Type Iron Deposits, [In:] Chalouan A., Rjimati E., MouttaqiMichard A., Saddiqi O., (Eds.), Nouveaux guides géologiques et miniers du Maroc, Notes de Mémoire de Services Géologiques du Ministčre de l'Energie des Hydrocarbures et des Mines du Maroc, 357-362.

Bouabdli, A., Saidi, N., El Founti, L., Leblanc, M., 2004. Impact de la mine d'Aouli sur les eaux et les sédiments de l'Oued Moulouya (Maroc). Bulletin de la Société d'histoire naturelle de Toulouse 140, 27-33.

Boujghad, A., Bouabdli, A., Baghdad, B., 2019. Groundwater quality evaluation in the vicinity of the Draa Sfar Mine in Marrakesh, Morocco. Euro-Mediterranean Journal for Environmental Integration 4(12), 1-10. https://doi.org/10.1007/s41207-018-0096-3 
Boularbah, A., Morel, J. L., Bitton, G., Mench, M., 1996. A direct solid-phase assay specific for heavy-metal toxicity. II. Assessment of heavy-metal immobilization in soils and bioavailability to plants. Soil and Sediment Contamination 5(4), 395-404. https://doi.org/10.1080/15320389 609383537

Boularbah, A., Schwartz, C., Bitton, G., Aboudrar, W., Ouhammou, A., Morel, J. L., 2006b. Heavy metal contamination from mining sites in South Morocco: 2. Assessment of metal accumulation and toxicity in plants. Chemosphere 63(5), 811-817. https://doi.org/10.1016/j.chemosphere.2005.07.076

Boularbah, A., Schwartz, C., Bitton, G., Morel, J. L., 2006a. Heavy metal contamination from mining sites in South Morocco: 1. Use of a biotest to assess metal toxicity of tailings and soils. Chemosphere 63(5), 802-810. https://doi.org/10.1016/j.chemosphere.2005.07.079

Boushaba, A., Michard, A., 2011. The Ait Ammar. Metamorphic Oolitic Iron (Central massif). [In :] Mouttaqi, A., Rjimati, E.C., Maacha, L., Michard, A., Soulaimani, A., Ibouh H. (Eds.), Nouveaux guides géologiques et miniers du Maroc (Volum 9), Notes de Mémoire de Services Géologiques du Ministčre de l'Energie des Hydrocarbures et des Mines du Maroc, 273-277.

Bouzekri, S., El Hachimi, M. L., Kara, K., El Mahi, M., Lotfi, E. M., 2020. Metal pollution assessment of surface water from the abandoned $\mathrm{Pb}$ mine Zaida, high Moulouya-Morocco. Geosystem Engineering 23 (4), 226-233. https://doi.org/10.1080/12269328.2020.1772125

Bouzekri, S., El Hachimi, M. L., Touach, N., El Fadili, H., El Mahi, M., 2019. The study of metal (As, $\mathrm{Cd}, \mathrm{Pb}, \mathrm{Zn}$ and $\mathrm{Cu}$ ) contamination in superficial stream sediments around of Zaida mine (High MoulouyaMorocco). Journal of African Earth Sciences 154, 49-58. https://doi. org/10.1016/j.jafrearsci.2019.03.014

Council of the European Communities., 1986. Directive (86/278/EEC) on the protection of the environment, and in particular of the soil, when sewage sludge is used in agriculture. Official Journal of the European Communities, L181, 6-12.

Dahmann, D., Morfeld, P., Monz, C., Noll, B., Gast, F., 2009. Exposure assessment for nitrogen oxides and carbon monoxide in German hard coal mining. International archives of occupational and environmental health 82(10), 1267-1279. https://doi.org/10.1007/s00420-009-0418-5

De Boer M.A., Wolzak L., Slootweg J.C., 2019. Phosphorus: Reserves, Production, and Applications. [In:] Ohtake H., Tsuneda S. (Eds.), Phosphorus Recovery and Recycling. Springer, Singapore, 75-100. https:// doi.org/10.1007/978-981-10-8031-9_5

El Aafi, N., Saidi, N., Maltouf, A. F., Perez-Palacios, P., Dary, M., Brhada, F., Pajuelo, E., 2015. Prospecting metal-tolerant rhizobia for phytoremediation of mining soils from Morocco using Anthyllis vulneraria L. Environmental Science and Pollution Research 22(6), 4500-4512. https://doi.org/10.1007/s11356-014-3596-y

El Adnani, M., Ait Boughrous, A., Yacoubi Khebiza, M., El Gharmali, A., Sbai, M. L., 2007. Impact des rejets miniers sur la qualité physicochimique et biologique des eaux souterraines d'une zone miničre dans la région de Marrakech (Maroc). Environmental Technology 28(1), 71-82.

El Adnani, M., Boughrous, A. A., Khebiza, M. Y., Sbai, M. L., Nejmeddine, A., 2006. Mine tailings impact on the physico-chemical and biological characteristics of underground waters in Marrakech mining area (Morocco). In 2006 First International Symposium on Environment Identities and Mediterranean Area, 287-293.

El Amari, K., Valera, P., Hibti, M., Pretti, S., Marcello, A., Essarraj, S., 2014. Impact of mine tailings on surrounding soils and ground water: Case of Kettara old mine, Morocco. Journal of African Earth Sciences 100, 437-449. https://doi.org/10.1016/j.jafrearsci.2014.07.017

EL Fadeli, S., Bouhouch, R., El-Abbassi, A., Lahrouni, M., Aziz, F., Benmazhar, H., Zimmermann, M. B., Sedki, A., 2015. Assessment of heavy metals contamination in soils around a mining site in Marrakech region, Morocco. Moroccan Journal of Chemistry 3(4), 3-4. https://doi. org/10.48317/IMIST.PRSM/morjchem-v3i4.3128
El Faiz, A., Duponnois, R., Winterton, P., Ouhammou, A., Meddich, A., Boularbah, A., Hafidi, M., 2015. Effect of different amendments on growing of Canna indica L. inoculated with AMF on mining substrate. International journal of phytoremediation 17(5), 503-513. https://doi. org/10.1080/15226514.2014.950408

El Gharmali, A., Rada, A., El Adnani, M., Tahlil, N., El Meray, M., Nejmeddine, A., 2004. Impact of acid mining drainage on the quality of superficial waters and sediments in the Marrakesh region, Morocco. Environmental Technology 25(12), 1431-1442. https://doi.org/10.108 0/09593332508618463

El Hachimi, M. L., Bouabdli, A., Fekhaoui, M., 2013. Les rejets miniers de traitement : caractérisation, capacité polluante et impacts environnementaux, mine Zed'da, mine Mibladen, Haute Moulouya (Maroc). Environnement and Techniques 323, 32-42. https://doi.org/10.4267/ dechets-sciences-techniques. 2567

El Hachimi, M. L., Fekhaoui, M., El Abidi, A., Rhoujatti, A., 2014. Contamination des sols par les métaux lourds ŕ partir de mines abandonnées : le cas des mines Aouli-Mibladen-Zed'da au Maroc. Cahiers Agricultures 23(3), 213-219. https://doi.org/10.1684/agr.2014.0702

El Hamiani, O., El Khalil, H., Lounate, K., Sirguey, C., Hafidi, M., Bitton, G., Schwartz, C., Boularbah, A., 2010. Toxicity assessment of garden soils in the vicinity of mining areas in Southern Morocco. Journal of Hazardous Materials 177(1-3), 755-761. https://doi.org/10.1016/ j.jhazmat.2009.12.096

El Hamiani, O., El Khalil, H., Sirguey, C., Ouhammou, A., Bitton, G., Schwartz, C., Boularbah, A., 2015. Metal concentrations in plants from mining areas in South Morocco: health risks assessment of consumption of edible and aromatic plants. Clean-Soil, Air, Water 43(3), 399-407. https://doi.org/10.1002/clen.201300318

El Himer, S., Bouabdli, A., Baghdad, B., Saidi, N., 2012. Contamination by trace metals (ETM) assessment of the plants populating the dump mining Zaida (High Moulouya, Morocco). Journal of Research in Agriculture 1, 49-54.

El Khalil, H., El Hamiani, O., Bitton, G., Ouazzani, N., Boularbah, A., 2008. Heavy metal contamination from mining sites in South Morocco: monitoring metal content and toxicity of soil runoff and groundwater. Environmental Monitoring and Assessment 136(1-3), 147-160. https://doi.org/10.1007/s10661-007-9671-9

El Kheir, S. B., Oubbih, J., Saidi, N., Bouabdli, A., 2008. Uptake and fixation of $\mathrm{Zn}, \mathrm{Pb}$, and $\mathrm{Cd}$ by Thlaspi caerulescens: application in the cases of old mines of Mibladen and Zaida (West of Morocco). Arabian Journal of Geosciences 1(2), 87-95. https://doi.org/10.1007/s12517008-0007-z

El Rasafi, T., Haddioui, A., 2020. Growth, Survival and Biomass Production of Barley in a Polluted Mine Soil Amended with Biochar and Animal Manure. Bulletin of Environmental Contamination and Toxicology 105(1), 155-165. https://doi.org/10.1007/s00128-020-02914-w

Esshaimi, M., Ouazzani, N., El Gharmali, A., Berkhis, F., Valiente, M., Mandi, L., 2013. Speciation of heavy metals in the soil and the mining residues, in the zinclead Sidi Bou Othmane abandoned mine in Marrakech area. Journal of Environment and Earth Science 3(8), 138-146. https://doi.org/10.15626/Eco-Tech.2010.102

Ghose, M. K., Kundu, N. K., 2004. Deterioration of soil quality due to stockpiling in coal mining areas. International Journal of Environmental Studies 61(3), 327-335. https://doi.org/10.1080/0020723032000093991

Hadi, H. E., 2015. Spatial distribution of soil heavy metals in the Zaida mine (Morocco) based on geostatistical methods. International Journal of Advanced Research 3(7), 337-349.

Hakkou, R., Benzaazoua, M., Bussičre, B., 2005. Environmental characterization of the abandoned Kettara mines wastes (Morocco). In Post Mining Symposia, Nancy (France), GISOS, 16-18.

Hakkou, R., Benzaazoua, M., Bussičre, B., 2008a. Acid mine drainage at the abandoned Kettara mine (Morocco): 1 . Environmental characterization. Mine Water and the Environment 27(3), 145-159. https://doi. org/10.1007/s10230-008-0036-6 
Hakkou, R., Benzaazoua, M., Bussiere, B., 2008b. Acid mine drainage at the abandoned Kettara mine (Morocco): 2. Mine waste geochemical behavior. Mine Water and the Environment 27(3), 160-170. https:// doi.org/10.1007/s10230-008-0035-7

Hakkou, R., Benzaazoua, M., Bussiere, B., 2009. Laboratory evaluation of the use of alkaline phosphate wastes for the control of acidic mine drainage. Mine Water and the Environment 28(3), 206-219. https:// doi.org/10.1007/s10230-009-0081-9

Iavazzo, P., Adamo, P., Boni, M., Hillier, S., Zampella, M., 2012a. Mineralogy and chemical forms of lead and zinc in abandoned mine wastes and soils: an example from Morocco. Journal of Geochemical Exploration 113, 56-67. https://doi.org/10.1016/j.gexplo.2011.06.001

Iavazzo, P., Ducci, D., Adamo, P., Trifuoggi, M., Migliozzi, A., Boni, M., $2012 \mathrm{~b}$. Impact of past mining activity on the quality of water and soil in the High Moulouya Valley (Morocco). Water, Air, and Soil Pollution 223(2), 573-589. https://doi.org/10.1007/s11270-011-0883-9

Ibouh, H., Hibti, M., Outhonjite, M., Essaoudi, M., Boukerrou, S., Zouhair, M., 2011. Le gisement polymétallique VMS de Draa Sfar (Jebilet centrales). [In :] Mouttaqi, A., Rjimati, E.C., Maacha, L., Michard, A., Soulaimani, A., Ibouh, H. (Eds.), Nouveaux guides géologiques et miniers du Maroc (Volum 9), Notes de Mémoire de Services Géologiques du Ministčre de l'Energie des Hydrocarbures et des Mines du Maroc, 215-218.

Jordán, G., D’Alessandro, M. (Eds.), 2004. Mining, mining waste and related environmental issues: problems and solutions in Central and Eastern European Candidate Countries. Joint Research Centre of the European Commission, Ispra, 208.

Kabata-Pendias A, Pendias H (Eds.), 2001. Trace elements in soils and plants, $3^{\text {rd }}$ Edn. CRC Press Inc, Boca Raton, Florida, USA.

Khalil, A., Hanich, L., Bannari, A., Zouhri, L., Pourret, O., Hakkou, R., 2013. Assessment of soil contamination around an abandoned mine in a semi-arid environment using geochemistry and geostatistics: prework of geochemical process modeling with numerical models. Journal of Geochemical Exploration 125, 117-129. https://doi.org/10.1016/ j.gexplo.2012.11.018

Lakrim, M., Mesrar, L., EL Aroussi, O., Lahrach, A., Beaabidate, L., Garouani, A., Chaouni, A., Tabyaoui, H., Jabrane, R., 2011. Etude d'impact des déchets miniers de la mine de Nador sur l'environnement (NordEst du Maroc). Revue Scientifique et Technique LJJE 18, 78-94.

Lakrim, M., El Aroussi, O., Mesrar, L., Jabrane, R., 2012. Localisation des zones vulnérables ŕ la contamination par le dma, moyennant le SIG : Cas de la mine de fer de nador (Maroc Nord Oriental). Geomaghreb 8, 15-23.

Lakrim, M., Mesrar, L., El Aroussi, O., Jabrane, R., 2016. Application géomatique pour la cartographie de la vulnérabilité environnementale engendrée par les déchets miniers de la mine ferrifere de Nador (Nord-est du Maroc). European Scientific Journal 12 (15), 287-307. https://doi.org/10.19044/esj.2016.v12n15p287

Lamin, H., Alami, S., Bouhnik, O., El Faik, S., Abdelmoumen, H., Bedmar, E. J., Missbah El Idrissi, M., 2019. Nodulation of Retama monosperma by Ensifer aridi in an abandoned lead mine soils in eastern Morocco. Frontiers in Microbiology 10, 1456. https://doi.org/10.3389/ fmicb.2019.01456

Lghoul, M., Maqsoud, A., Hakkou, R., Kchikach, A., 2014. Hydrogeochemical behavior around the abandoned Kettara mine site, Morocco. Journal of Geochemical Exploration 144, 456-467. https://doi.org/10.1016/ j.gexplo.2013.12.003

Madani, S., Coors, A., Haddioui, A., Ksibi, M., Pereira, R., Sousa, J. P., Römbke, J., 2015. Effects of contaminated soils from a former iron mine (Ait Amar, Morocco) on enchytraeids (Enchytraeus bigeminus) and predatory mites (Hypoaspis aculeifer) in standard laboratory tests. Ecotoxicology and Environmental Safety 119, 90-97. https://doi.org/10.1016/ j.ecoenv.2015.04.040

Makhoukh, M., Sbaa, M., Berrahou, A., Vanclooster, M., 2011. Contribution ŕ l'étude de l'impact d'un site minier abandonné dans la haute
Moulouya sur la qualité de l’Oued Moulouya, Maroc. Afrique Science : Revue Internationale des Sciences et Technologie 7(3), 33-48.

Marques, C. R., Caetano, A. L., Haller, A., Gonçalves, F., Pereira, R., Römbke, J., 2014. Toxicity screening of soils from different mine areas-A contribution to track the sensitivity and variability of Arthrobacter globiformis assay. Journal of Hazardous Materials 274, 331-341. https://doi.org/10.1016/j.jhazmat.2014.03.066

Matschullat J., Gutzmer J., 2012. Mining and Its Environmental Impacts. [In:] LaMoreaux, J. (Eds.), Environmental Geology. Encyclopedia of Sustainability Science and Technology Series. Springer, New York, 353-366. https://doi.org/10.1007/978-1-4939-8787-0_205

Mechali, D., Rodier, J., 1946. Lead Poisoning in a Lead-Mine in Morocco. Bulletin de l'Institut d'Hygične Maroc 6, 115-20.

Midhat, L., Ouazzani, N., Esshaimi, M., Ouhammou, A., Mandi, L., 2017. Assessment of heavy metals accumulation by spontaneous vegetation: Screening for new accumulator plant species grown in Kettara mineMarrakech, Southern Morocco. International Journal of Phytoremediation 19(2), 191-198. https://doi.org/10.1080/15226514.2016.1207604

Midhat, L., Ouazzani, N., Hejjaj, A., Bayo, J., Mandi, L., 2018. Phytostabilization of polymetallic contaminated soil using Medicago sativa $\mathrm{L}$. in combination with powdered marble: Sustainable rehabilitation. International Journal of Phytoremediation 20(8), 764-772. https://doi. org/10.1080/15226514.2018.1425665

Midhat, L., Ouazzani, N., Hejjaj, A., Ouhammou, A., Mandi, L., 2019. Accumulation of heavy metals in metallophytes from three mining sites (Southern Centre Morocco) and evaluation of their phytoremediation potential. Ecotoxicology and Environmental Safety 169, 150-160. https://doi.org/10.1016/j.ecoenv.2018.11.009

Mossa, J., James, L.A., 2013. Impacts of Mining on Geomorphic Systems. [In:] Shroder, J.F. (Eds.), Treatise on Geomorphology, Volume 13. Academic Press, San Diego, 74-95.

Moyé, J., Picard-Lesteven, T., Zouhri, L., El Amari, K., Hibti, M., Benkaddour, A., 2017. Groundwater assessment and environmental impact in the abandoned mine of Kettara (Morocco). Environmental Pollution 231, 899-907. https://doi.org/10.1016/j.envpol.2017.07.044

Nfissi, S., Alikouss, S., Zerhouni, Y., Hakkou, R., Benzaazoua, M., Bouzahzah, H., 2017. Control of acid mine drainage from an abandoned mine in Morocco by using cement kiln dust and fly ash as amendments. Journal of Materials and Environmental Sciences 8 (12), 4457-4466.

Nieva, N. E., Borgnino, L., García, M. G., 2018. Long term metal release and acid generation in abandoned mine wastes containing metal-sulphides. Environmental Pollution 242, 264-276. https://doi.org/10.1016/ j.envpol.2018.06.067

Nouri, M., 2016. Assessment of metals contamination and ecological risk in Ait Ammar abandoned iron mine soil, Morocco. Ekológia (Bratislava) 35(1), 32-49. https://doi.org/10.1515/eko-2016-0003

Nouri, M., Gonçalves, F., Sousa, J. P., Römbke, J., Ksibi, M., Pereira, R., Haddioui, A., 2014. Metal concentrations and metal mobility in Ait Ammar Moroccan mining site. Journal of Materials and Environmental Science 5(1), 271-280.

Nouri, M., Gonçalves, F., Sousa, J. P., Römbke, J. J., Ksibi, M., Pereira, R., Haddioui, A., 2013. Metal and phosphorus uptake by spontaneous vegetation in an abandoned iron mine from a semiarid area in center Morocco: Implications for phytoextraction. Environmental Research, Engineering and Management 64(2), 59-71. https://doi.org/10.5755/ j01.erem.64.2.3866

Nouri, M., Haddioui, A., 2017a. Diversity of soil microbial communities from an iron mining area (Oued Zem, Morocco). Materials and Geoenvironment 64(1), 21-34. doi: 10.1515/rmzmag-2017-0002

Nouri, M., Haddioui, A., 2017b. Evaluation of phytotoxicity of aitammar iron mine soil using garden cress (Lepidium sativum $\mathrm{L}$ ). The International Journal of Multi-disciplinary Sciences 1 (17), 46-54.

Nriagu, J. O., Pacyna, J. M., 1988. Quantitative assessment of worldwide contamination of air, water and soils by trace metals. Nature 333(6169), 134-139 
Oshokoya, P. O., Tetteh, M. N. M., 2018. Mine-of-the-future: How is Africa prepared from a mineral and mining engineering education perspective? Resources Policy 56, 125-133. https://doi.org/10.1016/ j.resourpol.2017.10.007

Ouaryi, A., Boularbah, A., Sanguin, H., Hafidi, M., Baudoin, E., Ouahmane, L., Le Roux, C., Galiana, A., Prin, Y., Duponnois, R. (2016). High potential of symbiotic interactions between native mycorrhizal fungi and the exotic tree Eucalyptus camaldulensis for phytostabilization of metal-contaminated arid soils. International Journal of Phytoremediation 18(1), 41-47. https://doi.org/10.1080/15226514.20 15.1058335

Probst, A., Liu, H., Fanjul, M., Liao, B., Hollande, E., 2009. Response of Vicia faba L. to metal toxicity on mine tailing substrate: geochemical and morphological changes in leaf and root. Environmental and Experimental Botany 66(2), 297-308. https://doi.org/10.1016/ j.envexpbot.2009.02.003

Raddi, Y., Essarraj, S., Michard, A. Le district plombifčre de la Haute Moulouya (Aouli-Mibladen, Zed'da)., 2011. [In :] Mouttaqi A., Rjimati E.C., Maacha L., Michard A., Soulaimani A., Ibouh H. (Eds.), Nouveaux guides géologiques et miniers du Maroc (Volum 9), Notes de Mémoire de Services Géologiques du Ministčre de l'Energie des Hydrocarbures et des Mines du Maroc.

Rodier, J., 1947. Lead Poisoning in the Lead Mines of Morocco. Bulletin de l'Institut d'Hygične Maroc 7, 101-17.

Salomons, W., 1995. Environmental impact of metals derived from mining activities: processes, predictions, prevention. Journal of Geochemical Exploration 52(1-2), 5-23. https://doi.org/10.1016/03756742(94)00039-E

Sbabou, L., Idir, Y., Bruneel, O., Le Quéré, A., Aurag, J., Béna, G., Filali-Maltouf, A., 2016. Characterization of root-nodule bacteria isolated from Hedysarum spinosissimum L, growing in mining sites of northeastern region of Morocco. SOJ Microbiology and Infectious Diseases 4(3), 1-8. http://dx.doi.org/10.15226/sojmid/4/3/00156

Sharma, A. K., Siddiqui, K. A., 2010. Assessment of air quality for an open cast coal mining area. Indian Journal of Scientific Research 1(2), 47-55.

Sheoran, V., Sheoran, A. S., Poonia, P., 2010. Soil reclamation of abandoned mine land by revegetation: a review. International Journal of Soil, Sediment and Water 3(2), 13
Simón, M., Ortiz, I., Garcýa, I., Fernández, E., Fernández, J., Dorronsoro, C., Aguilar, J., 1999. Pollution of soils by the toxic spill of a pyrite mine (Aznalcóllar, Spain). Science of the Total Environment 242(1-3), 105115. https://doi.org/10.1016/S0048-9697(99)00378-2

Taib, M., 2019. Morocco and Western Sahara. [In:] U.S. Geological Survey (Eds.), Minerals Yearbook, Area Reports, International Review: Africa and the Middle East. U.S. Government Printing Office, Washington, 359-370.

Toughzaoui, S., El Amari, K., Benkaddour, A., Hibti, M., Essarraj, S., 2015. Hydrogeochemical and isotopic studies of the Kettara mine watershed, Morocco. Mine Water and the Environment 34(3), 308-319. https://doi.org/10.1007/s10230-015-0326-8

WHO, 2008; Guidelines for drinking-water quality: second addendum. Vol.1, Recommendations, 3rd ed. World Health Organization. https:// apps.who.int/iris/handle/10665/204412

Wong, J. W. C., Ip, C. M., Wong, M. H., 1998. Acid-forming capacity of lead-zinc mine tailings and its implications for mine rehabilitation. Environmental Geochemistry and Health 20(3), 149-155. https://doi. org/10.1023/A:1006589124204

Yahyaoui, L., Essaifi, A., 2011. Massif des Jbilet (Meseta sud-occidentale). [In :] Michard A., Saddiqi O., Chalouan A., Rjimati E., Mouttaqi A. (Eds.), Nouveaux Guides géologiques et miniers du Maroc / New Geological and Mining Guide books of Morocco, Notes et Mémoires du Service géologique du Maroc, 71-82.

Zerhouni, Y., Alikouss, S., Saber, N., Nfissi, S., Zahour, G., Baroudi, Z., Mohamed, S., 2016. Caractérisation des boues de sucrerie et des argiles pour la neutralisation des résidus miniers acides de la mine de Kettara (Jebilet Centrales, Maroc). European Scientific Journal 12(15), 321-331. http://dx.doi.org/10.19044/esj.2016.v12n15p321

website 1: https://www.mem.gov.ma/Pages/secteur.aspx?e=7. Indicateurs Clés du Secteur Minier (Accessed June 17, 2020)

website 3: http://www.onhym.com/mines/les-provinces-metallogeniquesau-maroc.html. Les provinces métallogéniques au Maroc (Accessed June 17, 2020)

website 2: http://www.onhym.com/pdf/fr/Documentations/MINING_OVERVIEW_2018.pdf. Brochure: Mining Overview (Accessed June 20, 2020) 